\title{
Perpustakaan Digital Sebagai Media Publikasi Hasil Penelitian Arkeologi
}

\section{Hery Priswanto}

Keywords: public archaeology, library, research publication, service, data management

\section{How to Cite:}

Priswanto, H. (2007). Perpustakaan Digital Sebagai Media Publikasi Hasil Penelitian Arkeologi. Berkala Arkeologi, 27(2), 10-17. https://doi.org/10.30883/jba.v27i2.949

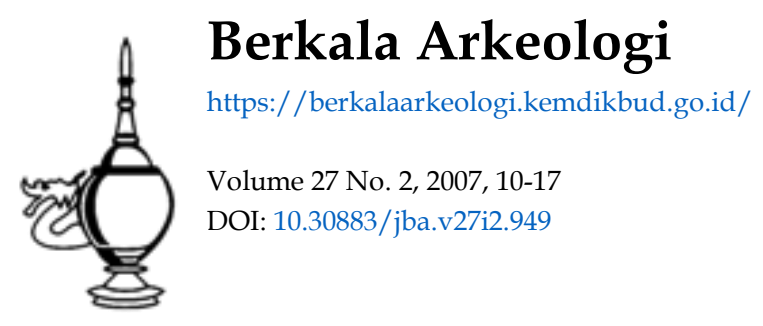




\title{
PERPUSTAKAAN DIGITAL SEBAGAI MEDIA PUBLIKASI HASIL PENELITIAN ARKEOLOGI
}

\author{
Hery Priswanto \\ (Balai Arkeologi Yogyakarta)
}

\begin{abstract}
Dalam rangka mewujudkan perpustakaan sebagai Information Resources Center, Perpustakaan Balai Arkeologi Yogyakarta dengan koleksi yang telah dimilikinya mulai untuk berbenah dengan berbagai upaya untuk mewujudkan perpustakaan digital dengan berbasis web. Yang diharapkan menjadi salah satu media publikasi dan informasi dokumentasi penelitian arkeologi yang telah dihasilkan Balai Arkeologi Yogyakarta kepada masyarakat.
\end{abstract}

\section{Pendahuluan}

Semua orang akan mudah menjawab ketika ditanya apakah perpustakaan itu? Sudah dapat dibayangkan dibenak kita bahwa di dalam perpustakaan tersimpan berderet buku-buku yang tersusun rapi di almari buku dan berbagai bacaan yang disediakan untuk keperluan penggunanya. Definisi perpustakaan menurut Undang-Undang Perpustakaan Nomor 43 Tahun 2007 yang baru saja di syahkan oleh DPR, adalah sebuah institusi pengelola koleksi karya tulis, karya cetak, dan atau karya rekam secara profesional dengan sistem yang baku guna memenuhi kebutuhan pendidikan, penelitian, pelestarian, informasi dan rekreasi para pemustaka. Undang-Undang Perpustakaan Nomor 43 Tahun 2007 terdiri dari 15 bab dan 54 pasal adalah sebuah landasan legal formal perpustakaan untuk memberi landasan dan arah perustakaan di Indonesia.

Keberadaan perpustakaan muncul dikarenakan adanya tuntutan persyaratan-persyaratan tertentu dan bukan karena tuntutan kebutuhan. Menurut, jenis perpustakaan, Perpustakaan Balai Arkeologi Yogyakarta merupakan sebuah perpustakaan khusus yang keberadaannya diperuntukkan secara terbatas bagi pemustaka di lingkungan Balai Arkeologi Yogyakarta atau pemerhati bidang ilmu sejarah, antropologi, dan arkeologi. 
Berkembangnya paradigma perpustakaan tidak hanya sekedar jajaran buku, namun perpustakaan lebih berperan sebagai sumber daya informasi (Information Resources Center). Perpustakaan diperlukan untuk mendukung tercapainya proses belajar - mengajar, riset, pengembangan ilmu dan rekreasi. Peran perpustakaan sebagai sumber daya informasi diharapkan dapat memberikan layanan yang prima dan paripurna bagi penggunanya. Koleksi dan informasi yang beraneka ragam yang dimiliki perpustakaan bermanfaat untuk mengubah cara berpikir, bertingkah laku dan berperasaan dalam menghadapi proses perubahan kehidupan. Perubahan ini tentunya juga harus dihadapi dan diikuti institusi perpustakaan dan pustakawannya. (Supriyanto, 2002: 12)

Seiring dengan berkembangnya teknologi informasi dan komunikasi dalam berbagai bidang kehidupan, mau tidak mau keberadaan perpustakaan harus dapat memanfaatkan momen ini. Kemampuan penguasaan teknologi informasi dan komunikasi akan sangat penting dalam menghadapi berbagai tantangan dan kebutuhan di masa depan karena pemanfaatan dan penggunaan teknologi informasi dan komunikasi ini akan menjadi tulang punggung bagi pendayagunaan koleksi dan meningkatkan akses informasi. (Sudarsono, 1997).

Teknologi informasi dan komunikasi berbasis digital memiliki pengaruh yang sangat luas dengan perpustakaan. Teknologi diciptakan untuk memberi kemudahan dan kenyaman sistem kerja yang berujung pada peningkatan efisiensi, produktivitas, dan kualitas hasil yang prima. Informasi yang melimpah dan mudah diperoleh sebagai konsekuensi logis akibat globalisasi dan transparansi serta nilai penting informasi, muncul tuntutan-tuntutan untuk mendapatkan informasi dengan berdasar pada relevansi, akurasi, dan tepat waktu. (Supriyanto, 2002: 10)

\section{Perpustakaan Digital}

\subsection{Definisi dan Sejarah Perpustakaan Digital}

Beberapa istilah digunakan untuk mengungkapkan konsep perpustakaan digital (Digital Library) seperti perpustakaan elektronik (e-Library), dan perpustakaan maya (Virtual Library), Pada dasarnya, perpustakaan digital itu sama saja dengan perpustakaan konvensional. Perpustakaan 
konvensional koleksinya berupa kumpulan buku tercetak, film mikro (microfilm dan microfiche), ataupun kumpulan kaset audio, dan video; dengan sistem pencarian koleksi secara manual melalui kartu-kartu katalog yang sangat tidak efisien. Sementara itu koleksi perpustakaan digital berupa data dengan format digital. berada dalam suatu komputer server yang bisa ditempatkan secara lokal, maupun di lokasi yang jauh, namun dapat diakses dengan cepat dan mudah lewat jaringan komputer (Internet). Koleksi perpustakaan digital tidaklah terbatas pada dokumen elektronik pengganti bentuk cetak saja, ruang lingkup koleksinya malah sampai pada artefak digital yang tidak bisa digantikan dalam bentuk tercetak. Koleksi menekankan pada isi informasi, jenisnya dari dokumen tercetak sampai hasil penelusuran.

Istilah perpustakaan digital pertama kali diperkenalkan lewat proyek NSF/ DARPANASA: Digital Libraries Initiative pada tahun 1994. Perpustakaan digital yang paling banyak dikenal saat ini adalah Proyek Gutenberg, ibiblio dan Internet Archive, serta proyek yayasan Wikimedia. Embrio perpustakaan digital di Indonesia adalah eksperimen sekelompok hobbyist di Perpustakaan Pusat Institut Teknologi Bandung (ITB). Mereka memprakarsai Jaringan Perpustakaan Digital Indonesia bekerja sama dengan Computer Network Research Group (CNRG) dan Knowledge Management Research Group (KMRG). Proyek ini dimaksudkan untuk meningkatkan mutu pendidikan tinggi, menumbuhkan semangat berbagi pengetahuan antar pendidikan tinggi dan lembaga penelitian melalui pengembangan jaringan nasional perpustakaan.

Perpustakaan Balai Arkeologi Yogyakarta yang memberikan dukungan kepada Balai Arkeologi Yogyakarta untuk menjalankan tugas pokok dan fungsi lembaga mempunyai harapan untuk berperan penting dalam mengisi subsistensi informasi melalui sistem jaringan komputer dan berbasis web (internet) yang multi-user dan accessable, sehingga Perpustakaan Balai Arkeologi Yogyakarta berperan sebagai salah satu pusat informasi arkeologi, yang memberikan informasi data-data hasil penelitian arkeologi, dokumentasi multimedia dan sumber belajar - riset yang capable. 


\subsection{Software Perpustakaan Arkeologi Digital}

Digitalisasi Perpustakaan Balai Arkeologi Yogyakarta sudah dirintis mulai tahun 2006, yang kemudian pada pertengahan bulan Juni 2007 Program Sistem Informasi Perpustakaan Terpadu mulai diujicobakan dengan menggunakan software IBRA Versi_03. Penggunaan IBRA Versi_03 dikarenakan lebih informatif, atraktif, dan interaktif dalam menyajikan semua data koleksi secara digital.

IBRA (Integrated Library Information System) ini diperkenalkan dan dikembangkan oleh Teratama Technology System Yogyakarta. Program ini bersifat client-server, multi user, berbasis web dengan sistem operasi Windows, Machintos, atau Linux. IBRA Versi_03 merupakan perkembangan Versi_01 yang muncul pada tahun 2005 untuk mendukung sistem manajemen pustaka cetakan, yang kemudian disusul dengan Versi_02 pada tahun 2006 dengan tambahan untuk manajemen pustaka digital (ebook). Pada Versi_03 ini mempunyai kemampuan untuk mendukung manajemen pustaka multimedia sekaligus, disamping pustaka cetakan dan pustaka digital. (Anonim, 2007: 1)

\subsubsection{Peralatan dan Perlengkapan}

Untuk mendukung software IBRA ini diperlukan beberapa peralatan dan perlengkapan yaitu :

a. Hardware

- Komputer dengan spesifikasi yaitu Pentium III $600 \mathrm{MHz}$, Memory 128, Media Simpan (Hard Disk) $40 \mathrm{Ghz}$.

Ini merupakan spesifikasi minimal untuk dapat menjalankan software IBRA Versi_03 untuk mengelola koleksi pustaka cetakan dan pustaka digital. Apabila untuk mengelola pustaka multimedia sekaligus sangat disarankan untuk menggunakan Processor dan Memory dengan kapasitas tinggi dan media simpan yang besar.

- Monitor Server dan Monitor Opac (Online public access).

Keberadaan monitor merupakan satu paket dengan komputer, namun untuk keperluan perpustakaan digital diperlukan minimal dua monitor yaitu sebagai monitor server dan monitor Opac. Monitor server dipergunakan untuk kegiatan entry-editing-launching 
database perpustakaan sedangkan monitor Opac berfungsi sebagai media visual pemustaka untuk pencarian database perpustakaan.

- Printer \& Scanner

Hardware printer dan scanner juga sangat berperan untuk mendukung software IBRA Versi_03 terutama untuk scanning dan printing. Sekarang sudah dapat ditemukan di pasaran produk printer sekaligus scanner, hardware ini yang disarankan. Kegiatan scanning melalui mesin scanner berfungsi memindahkan data manual ke digital dengan ekstensi PDF (Portable Document Format) untuk format tulisan dan ekstensi JPEG untuk format gambar. Kegiatan printing berfungsi untuk memberikan layanan kepada pemustaka untuk mendapat cetakan database, administrasi perpustakaan, dan mengganti cover buku yang sudah rusak

b. Software

- Browser Internet: Mozilla Firefox, Internet Explorer, Netscape Navigator, Opera.

Software ini diperlukan untuk proses kegiatan entry-editinglaunching data base perpustakaan.

- Pengolah Gambar : Adobe Photoshop, ACDSee

Software Adobe Photoshop dan ACDsee digunakan sebagai untuk proses scanning gambar maupun teks (PDF), media visual untuk pustaka multimedia dan sekaligus berfungsi sebagai pengolah gambar.

- Media Baca (Format Pdf): Acrobat Profesional, Acrobat Reader Berfungsi sebagai media baca dengan format PDF maupun untuk scanning data dengan format PDF.

- Media Player: Windows Media Player, Media Player Classic Berfungsi sebagai media visual untuk melihat koleksi pustaka multimedia. 


\subsubsection{Proses Digitalisasi Koleksi Perpustakaan}

a. Komputer Server

Pengelolaan Perpustakaan Balai Arkeologi untuk koleksi pustaka cetakan sudah melalui proses entry data ke program IBRA Versi_03 sehingga pencarian semua koleksi perpustakaan dilakukan secara digital. Kegiatan entry data dan scanning dilakukan di komputer Server yang dilakukan oleh petugas perpustakaan yang merupakan akses level pertama. Pada level ini mempunyai kewenangan untuk kegiatan entry-editing-launching database perpustakaan.

b. Komputer Opac (Online public access).

Pemustaka (user) akan sangat mudah sekali untuk mengakses semua koleksi perpustakaan melalui Monitor Opac (Online public access). Opac merupakan fasilitas bagi user untuk mengakses database perpıstakaan. Pemustaka hanya dapat mengakses database dan tidak dapat melakukan editing database. Dengan Opac ini, penelusuran infomasi data koleksi perpustakaan dipermudah dengan adanya tampilan sampul buku selain itu juga dilengkapi dengan kata kunci (keyword) subyek yang lebih spesifik.

\subsubsection{Format-Format Kemasan Pustaka}

Format-format kemasan pustaka yang dimiliki perpustakaan digital inilah yang menbedakan dengan koleksi perpustakaan konvensional. Formatformat kemasan pustaka (Priyo DA, 2007: 1 -3) meliputi :

a. Pustaka Cetakan

Pustaka cetakan yang dimaksud adalah koleksi perpustakaan berupa koleksi buku-buku cetakan (offset) atau hard copy. Pustaka cetakan meliputi textbook, Karya IImiah (Skripsi, Tesis, Disertasi), Laporan Penelitian, Terbitan Berkala (Majalah, Koran, Buletin, Jurnal).

Penelusuran koleksi pustaka pada perpustakaan digital akan mendapatkan informasi mengenai judul, cover, pengarang, jumlah, status buku, serta buku -buku yang berkorelasi sesuai dengan kata kunci (keyword) yang diketik di mesin pencari. Penelusuran koleksi 
pustaka pada perpustakaan digital lebih cepat dan banyak informasi yang diperoleh apabila dibandingkan dengan sistem kartu katalog perpustakaan konvensional

b. Pustaka Digital

Pustaka digital meliputi e-Book, artikel, kliping, makalah, hasil penelitian dan karya tulis ilmiah (Skripsi, Tesis, Disertasi) dengan format PDF. Untuk mendapatkan pustaka digital dapat melalui Opac yang akan menyajikan informasi berupa judul dan pengarang. Pada pustaka digital, user dapat langsung membaca pustaka digital yang dikehendaki dengan menggunakan media baca Acrobat Reader.

c. Pustaka Multimedia

Pustaka multimedia merupakan kumpulan pustaka berupa rekaman video, Rekaman Audio, CD/DVD, dan Image (Foto). Pada pustaka multimedia ini koleksi rekaman video, audio, dan CD/DVD tidak ditampilkan secara full version melainkan dalam bentuk klip yang disertai abstraksi. Sedangkan koleksi berupa Image (foto) yang diakses hanya yang representatif saja.

Pada pustaka multimedia inilah, user akan dapat mengakses beberapa koleksi film hasil penelitian Balai Arkeologi Yogyakarta maupun filmfilm dokumenter lainnya.

\section{Penutup}

Proses kegiatan digitalisasi perpustakaan Balai Arkeologi Yogyakarta masih berjalan dan akan terus berjalan. Sosialisasi program perpustakaan digital terhadap para anggota dan para pengguna sangatlah penting, peningkatan kesadaran memberikan kemudahan akses terhadap informasi dan mendorong pengguna perpustakaan digital untuk melek informasi (Information Literate). Dengan mengutamakan ketepatan, keabsahan, dan keterpaduan sumber informasi yang disajikannya. Di kemudian hari diharapkan Perpustakaan Digital Balai Arkeologi Yogyakarta akan menjadi "Resources Center" dengan mengembangkan Sistem Informasi Perpustakaan Arkeologi Terpadu, yang mengakomodasikan semua hasil- 
hasil penelitian dalam berbagai bentuk cetakan maupun multimedia terintegrasi didalam satu sistem, dalam upaya mempresentasikan hasil penelitian arkeologi publik yang lebih assessable.

\section{KEPUSTAKAAN}

Anomim, 2007, Profil \& Simple Manual Sistem Informasi Perpustakaan

Terpadu IBRA V.3, Yogyakarta: Teratama Technology System

Priyo, DA. 2007. "Sistem Informasi Perpustakaan Terpadu" dalam Buletine Sangkakala Edisi IV. Yogyakarta: Badan Perpusda Prop DIY.

Sudarsono; B. 1997., "Perencanaan Strategi Perpustakaan Perguruan Tinggi”, dalam Seri Pengembangan Perpustakaan 3: Perpustakaan Menjawab Tantangan Jaman. Editor F.A. Wiranto dkk, Semarang: Penerbit Soegijapranata).

Supriyanto, Yp. 2002. "Perilaku Pemakai Perpustakaan" dalam Info PERSADHA Vol. $1 /$ No. 2 hal. 12

Suroyudo, Y. Agustirto. 2007. "Undang-Undang Perpustakaan dan Asa Baru Dunia Perpustakaan" dalam Buletine Sangkakala Edisi IV, Yogyakarta: Badan Perpusda Prop DIY.

http://CDC-FTUl.edu.id/

http://id.wikipedia.org/wiki/Perpustakaan digital

Kompas, 2007, Pustakawan Bukan Sekedar Penjaga Buku, Jakarta: Gramedia, Kompas Kamis 25 Oktober 2007 hal. 12.

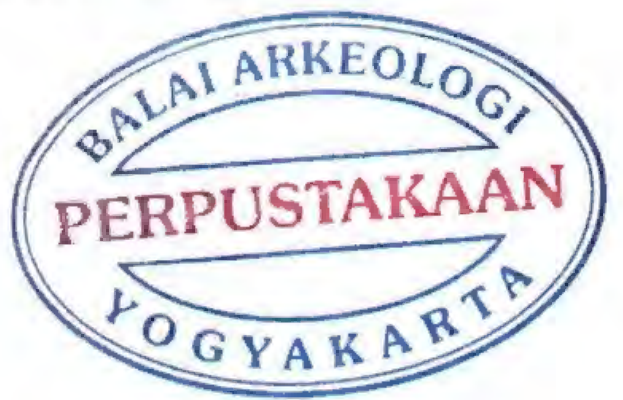

